\section{International Scientific Journal Theoretical \& Applied Science}

p-ISSN: 2308-4944 (print) e-ISSN: 2409-0085 (online)

Year: $2016 \quad$ Issue: 9 Volume: 41

Published: $30.09 .2016 \quad \underline{\text { http://T-Science.org }}$

SECTION 31. Economic research, finance, innovation, risk management.
Aibek Bakhytzhanuly Salhogaev Muster student of Kazakh

Engineering and Pedagogical University of Nations Friendship.

Aigul Kuanyshevna Kupesheva Candidate of economical science. Chief of department of Kazakh

Engineering and Pedagogical University of Nations Friendship.

Ersultan Zhomartovich Shalkhar Muster student of Kazakh

Engineering and Pedagogical

University of Nations Friendship.

Nurlan Muhtarovich Batyrbaev Candidate of law science, professor. Vice president of International KazakhTurkish University after H.A.Yessevi.

Erkin Shazhievich Dusipov

Doctor of law science, professor. Zhetysu state University after I.Zhansugurov.

Yernar Sailaubekovich Shalkharov Master of law, economics, bachelor Of biology. Corresponding member Of Theoretical and Applied Science Academy. General director of BeinAgroIndustries LTD. yernar_shalkharov@bk.ru

\title{
AN ANALYSIS OF THE FEASIBILITY OF THE UPGRADING MODERNIZATING OPERATIONAL ANALYSIS OF AUDIT RESULTS, COUNT LECTURING, ACCOUNTING AND OTHER FINANCIAL ACTIVITIES OF SMALL AND MEDIUM SIZED ENTERPRISES IN KAZAKHSTAN
}

Abstract: Operational analysis is by far one of the key mechanisms for effective data analysis and processing in industrial and non-industrial enterprises. Accordingly, the level of development of such tools is the key to the success and effectiveness of any enterprise in a market society. While many payment transactions are formed on the basis of absolute calculation functionality and feasibility of operating systems it depends on their level of development.

Key words: Operational analysis, key mechanisms, consumer data, trading index, non-industrial enterprises, accounting services.

Language: English

Citation: Salhogaev AB, Kupesheva AK, Shalkhar EZ, Batyrbaev NM, Dusipov AS, Shalkharov YS (2016) AN ANALYSIS OF THE FEASIBILITY OF THE UPGRADING MODERNIZATING OPERATIONAL ANALYSIS OF AUDIT RESULTS, COUNT LECTURING, ACCOUNTING AND OTHER FINANCIAL ACTIVITIES OF SMALL AND MEDIUM SIZED ENTERPRISES IN KAZAKHSTAN. ISJ Theoretical \& Applied Science, 09 (41): 142-144.

\section{Soi: http://s-o-i.org/1.1/TAS-09-41-22 Doi: crossef http://dx.doi.org/10.15863/TAS.2016.09.41.22}

\section{Introduction}

In a market economy the enterprise well-being depends on the size of the profits. Wanted reasonable and balanced approach in taking both strategic and tactical decisions based on widespread use of economic methods [1]. 
To develop a wide range of administrative decisions used quite regularly so-called operational analysis (or analysis of the relationship "costs production volume - profit") [2]. This is one of the most effective methods for operational and strategic planning and performance management of the company, which is based on the linear relationship between the size of the release of goods, the sales proceeds and costs of the enterprise [3].

\section{Materials and Methods}

Operational Analysis - one of the most effective methods for analyzing the impact of the cost structure and revenue on product profitability and ultimately the effectiveness of the enterprise [4]. It allows through modeling to find the most advantageous ratio between variable and fixed costs, the cost of production and the volume of production. Its effectiveness is determined by the fact that the analysis brings together market research, cost accounting, financial analysis and production planning (A. Brown "Operational analysis as an approach to pricing") [5].

Application operational analysis also allows to determine the minimum value of the order. Operational analysis helps to determine the most advantageous combination of the relationship between the variable costs per unit of output, fixed costs, the price and volume of production [6].

Operational analysis allows to find the most advantageous ratio between variable and fixed costs, the price and volume of production. The main role in the selection of the company strategy of behavior belongs indicator of marginal income [7]. A key element of the operational analysis performs calculation of break-even point, the threshold of profitability, safety margin and operating leverage [8].

The results of operational analysis necessary for the management of the enterprise acceptance of correct administrative decisions. With the help of the operational analysis reserves defined, provides an objective assessment of the production reserves and the extent of their use, the obvious real deficit or loss of resources, the objective need for them to increase production or increase existing resources. On the basis of the operational analysis developed ways of mobilizing reserves, the possibility of their resources and financial support [9].

Operational analysis uses the entire range of economic information is internal and operational nature, so has the ability to realistically assess the state of the organization, to investigate the cost structure of the issued and sold products and some of its species composition of the commercial and administrative expenses, allowing carefully examine the nature of the job responsibility persons for the resulting deflection [10].

These operational analysis play a crucial role in the development of the most important issues of competition policy of the company, managers are used to improve the technology and organization of production, to create a mechanism to achieve maximum profit [11].

An essential element of the operating costs analysis is the study of the structure, that is, the ratio of variable and fixed costs of the enterprise. And there is some sort of unified recommendations on the best cost structure even within the same industry. Their optimal ratio depends on the specific conditions of the enterprise and the influencing factors, including the long-term trend and the annual fluctuations in the level of sales, and so on. $\mathrm{N}$ [12].

Performance management mechanism of the enterprise using the "Interconnection costs, sales volume and profit" system is based on its dependence on the following factors: a) the volume of sales; b) the amount and the level of net operating income; c) the amount and level of variable operating costs; g) the amount of fixed operating costs; d) the ratio of fixed and variable operating costs [13].

These factors can be considered as basic in the formation of the amount of different types of income, working on that you can get the desired results, increasing the efficiency of the enterprise [14].

One of the simplest and most effective methods of operational analysis for the purpose of operational and strategic management of profits is to analyze the "cost - volume - profit", which allows you to track the relationship of business financial performance. Analysis of "cost - volume - profit" is to answer the most important questions faced by venture financiers on four main stages of money turnover [15].

\section{Conclusion}

With the simplicity of the model used operational analysis is attractive because the information base for it are data available on the total revenues and total costs of the company for several of the analyzed periods. Analysis of the Relationship "costs - production volume - profit" allows us to solve many analytical problems and serves as a powerful information tool for the preparation of administrative decisions. With the help of this analysis identifies important to control the value: break-even point, the security indicator, operational risk and the critical level of selling prices. 


\begin{tabular}{|c|c|c|c|c|c|c|}
\hline Impact Factor: & $\begin{array}{l}\text { ISRA (India) } \\
\text { ISI (Dubai, UAF } \\
\text { GIF (Australia) } \\
\text { JIF }\end{array}$ & $\begin{array}{l}=1.344 \\
=0.829 \\
=0.564 \\
=1.500\end{array}$ & $\begin{array}{l}\text { SIS (USA) } \\
\text { PИНЦ (Russia) } \\
\text { ESJI (KZ) } \\
\text { SJIF (Morocco) }\end{array}$ & $\begin{array}{l}=0.912 \\
=0.234 \\
=1.042 \\
=2.031\end{array}$ & $\begin{array}{l}\text { ICV (Poland) } \\
\text { PIF (India) } \\
\text { IBI (India) }\end{array}$ & $\begin{array}{l}=6.630 \\
=1.940 \\
=4.260\end{array}$ \\
\hline
\end{tabular}

\section{Background}

For a whole competent it is actual to notice that all issues in articles were formulated from the surveys of BeinAgroIndustries LTD. Also, it is important to mention together work of two university staff: Kazakh Engineering and Pedagogical University of Nations Friendship and International Kazakh-Turkish University after Khoga Akhmet Yassavi. In case of novelty, p.t.value the main author is the last in the list of authors.

\section{References:}

1. Corrado Zoppi, Sabrina Lai (2013) Differentials in the regional operational program expenditure for public services and infrastructure in the coastal cities of Sardinia (Italy) analyzed in the ruling context of the Regional Landscape Plan. Original Research Article Land Use Policy, Volume 30, Issue 1, January 2013, Pages 286-304.

2. Wiesław Olek, Romain Rémond, Jerzy Weres, Patrick Perré (2016) Non-Fickian moisture diffusion in thermally modified beech wood analyzed by the inverse method. Original Research Article International Journal of Thermal Sciences, Volume 109, November 2016, Pages 291-298.

3. Taojun Wang, Liang Zhao, Yanan Sun, Fazheng Ren, Shanbin Chen, Hao Zhang, Huiyuan Guo (2016) Changes in the microbiota of lamb packaged in a vacuum and in modified atmospheres during chilled storage analysed by high-throughput sequencing. Original Research Article. Meat Science, Volume 121, November 2016, Pages 253-260.

4. Yuto Konishi, Kazunori Kadota, Yuichi Tozuka, Atsuko Shimosaka, Yoshiyuki Shirakawa (2016) Amorphization and radical formation of cystine particles by a mechanochemical process analyzed using DEM simulation. Original Research Article. Powder Technology, Volume 301, November 2016, Pages 220-227.

5. Zhaoru Zhang, Timo Vihma, Achim Stössel, Petteri Uotila (2015) The role of wind forcing from operational analyses for the model representation of Antarctic coastal sea ice. Original Research Article Ocean Modelling, Volume 94, October 2015, Pages 95-111.

6. M. Nachon, N. Mangold, O. Forni, L.C. Kah, A. Cousin, R.C. Wiens, R. Anderson, D. Blaney, J.G. Blank, F. Calef, S.M. Clegg, C. Fabre, M.R. Fisk, O. Gasnault, J.P. Grotzinger, R. Kronyak, N.L. Lanza, J. Lasue, L. Le Deit, S. Le Mouélic, S. Maurice, et al. (2016) Chemistry of diagenetic features analyzed by ChemCam at Pahrump Hills, Gale crater, Mars.
Original Research Article. Icarus, In Press, Corrected Proof, Available online 1 September 2016.

7. Georgina Sauzier, Dana Bors, Jordan Ash, John V. Goodpaster, Simon W. Lewis (2016) Optimisation of recovery protocols for doublebase smokeless powder residues analysed by total vaporisation (TV) SPME/GC-MS. Original Research Article. Talanta, Volume 158, 1 September 2016, Pages 368-374.

8. Ove Mørck, Manuela Almeida, Marco Ferreira, Nelson Brito, Kirsten Engelund Thomsen, Iben Østergaard (2016) Shining examples analysed within the EBC Annex 56 project. Original Research Article. Energy and Buildings, Volume 127, 1 September 2016, Pages 991-998.

9. Gomes LC, Carvalho D, Briandet R, Mergulhão FJ (2016) Temporal variation of recombinant protein expression in Escherichia coli biofilms analysed at single-cell level. Original Research Article. Process Biochemistry, Volume 51, Issue 9, September 2016, Pages 1155-1161.

10. Oleg Heczko, Petr Cejpek, Jan Drahokoupil, Václav Holý (2016) Structure and microstructure of $\mathrm{Ni}-\mathrm{Mn}-\mathrm{Ga}$ single crystal exhibiting magnetic shape memory effect analysed by high resolution X-ray diffraction. Original Research Article. Acta Materialia, Volume 115, 15 August 2016, Pages 250-258.

11. Andreas Ulbig, Göran Andersson (2015) Analyzing operational flexibility of electric power systems. Original Research Article. International Journal of Electrical Power \& Energy Systems, Volume 72, November 2015, Pages 155-164.

12. Miguel Ramirez de la Huerga, Victor A. Bañuls Silvera, Murray Turoff (2015) A CIA-ISM scenario approach for analyzing complex cascading effects in Operational Risk Management. Original Research Article. Engineering Applications of Artificial Intelligence, Volume 46, Part B, November 2015, Pages 289-302. 